Jurnal Ilmu Sosial dan Pendidikan (JISIP)

Vol. 5 No. 3 Juli 2021

Terakreditasi Peringkat 5 (No. SK: 85/M/KPT/2020)

e-ISSN : 2656-6753, p-ISSN: 2598-9944

DOI: 10.36312/jisip.v5i3.2226/http://ejournal.mandalanursa.org/index.php/JISIP/index

\title{
Kebebasan Berdagang Di Tengah PPKM Darurat Ditinjau Dari Sudut Pandang Sosiological Jurisprudence Dan Konsep Keadilan
}

\author{
${ }^{1}$ Sukendar, ${ }^{2}$ Aris Prio Agus Santoso, ${ }^{3}$ Raden Ade Rifai, ${ }^{4}$ Risma Dewi Hermawan \\ ${ }^{1,3}$ STIH Pelopor Bangsa Depok, \\ ${ }^{2,4}$ Universitas Duta Bangsa Surakarta
}

\begin{tabular}{l}
\hline Article Info \\
\hline Article history: \\
Article Reseived: 18 July 2021 \\
Publication: 20 July 2021
\end{tabular}

\section{Kata Kunci:}

Kebebasan

Sosiological

Keadilan

\begin{tabular}{l}
\hline Article Info \\
Article history: \\
Article Reseived : 18 July 2021 \\
Publication: 20 July 2021
\end{tabular}

Keyword

freedom of trade, sociological jurisprudence, justice.

\begin{abstract}
Abstrak
Pemerintah telah menerapkan Kebijakan Pemberlakuan Pembatasan Kegiatan Masyarakat (PPKM) Darurat yang berdampak pada sektor perdagangan, salah satunya adalah pelaku UMKM. Pelaku UMKM selain mengalami penurunan omset juga memperoleh sanksi pidana denda di tengah PPKM darurat ini oleh pemerintah setempat. Perumusan masalah dalam penelitian ini adalah bagaimana kebebasan berdagang di tengah PPKM darurat ditinjau dari sudut pandang sosiological jurisprudence dan keadilan. Metode pendekatan yang digunakan dalam penelitian ini adalah pendekatan yuridis normatif, dengan pengumpulan data sekunder. Pengambilan data dalam penelitian ini adalah dengan studi pustaka. Hasil yang diperoleh dianalisis secara kualitatif. Dari hasil penelitian menunjukkan bahwa secara konsep sociological jurisprudence, berdagang di tengah PPKM darurat merupakan hak masyarakat yang menjadi realitas publik yang harusnya tetap dipantau dan dikontrol tanpa penjatuhan sanksi denda meskipun asas Salus Populi Suprema Lex Esto menjadi landasan dalam implementasi sanksi tersebut. Akan tetapi, paling tidak cita hukum harus tetap dipertimbangkan demi merubah nilai sosial dalam masyarakat tersebut. Secara konsep keadilan, berdagang di tengah PPKM darurat merupakan hak setiap orang untuk mempertahankan hidup dan kehidupanya yang telah dirumuskan oleh hukum dalam bentuk hak dan kewajiban. Ini menegaskan bahwa Pemerintah tetap harus memperhatikan suatu keadilan dengan mempertimbangkan faktor ekonomi dan sosial, yang tentunya harus relevan dengan ketertiban umum dimana suatu skala keadilan diakui.
\end{abstract}

Abstract
The government has implemented a Policy for the Imposition of Restrictions
on Emergency Community Activities that have an impact on the trade sector, one
of which is micro, small and medium enterprises. These business actors, in
addition to experiencing a decrease in turnover, also received criminal sanctions
in the midst of the imposition of this emergency Community Activity Restriction
by the local government. The formulation of the problem in this study is how
freedom of trade in the midst of the Imposition of Restrictions on Emergency
Community Activities is viewed from the point of view of sociological
jurisprudence and justice. The approach method used in this study is a normative
juridical approach, with secondary data collection. Data collection in this
research is by literature study. The results obtained were analyzed qualitatively.
From the results of the study, it shows that in sociological jurisprudence, trading
in the midst of the Imposition of Restrictions on Emergency Community Activities
is a community right that becomes a public reality that should still be monitored
and controlled without imposing fines even though the Salus Populi Suprema Lex
Esto principle is the basis for implementing these sanctions. However, at least
the legal ideals must still be considered in order to change social values in the
community. In the concept of justice, trading in the midst of the Imposition of
Restrictions on Emergency Community Activities is the right of everyone to
defend their life and life which has been formulated by law in the form of rights
and obligations. This emphasizes that the Government must still pay attention to
justice by considering economic and social factors, which of course must be
relevant to public order where a scale of justice is recognized.
This is an open access article under the Lisensi Creative Commons Atribusi-BerbagiSerupa 4.0 Internasional

This is an open access article under the Lisensi Creative Commons Atribusi-BerbagiSerupa 4.0 Internasional 
Corresponding Author:

\section{Sukendar}

STIH Pelopor Bangsa Depok

Email: sukendarlaw@gmail.com

\section{PENDAHULUAN}

World Health Organization (WHO) telah menetapkan Corona Virus Disease 2019 (COVID19) sebagai pandemi global pada Rabu, 11 Maret 2020. Penetapan tersebut didasarkan pada sebaran 118 ribu kasus yang menjangkiti di 114 negara. Sebelumnya COVID-19 pertama kali terdeteksi di kota Wuhan, RRT pada akhir desember 2019, dan kemudian menjadi wabah di januari 2020. Gejala dari COVID-19 ini, sangat mirip dengan gejala flu disertai dengan pneumonia (radang paru), yang mengakibatkan pasien menjadi sesak (sulit bernafas). Hal inilah yang menyebabkan meningkatnya angka kematian akibat virus ini.

Data dari Jhons Hopkins School merilis lebih dari 3.754.650 kasus postif COVID-19 secara global dengan 1.246.184 kasus dinyatakan pulih dari virus dan 263.861 kasus meninggal dunia1. Di Indonesia kasus positif telah mencapai 12.438 kasus positif dengan 2.317 kasus dinyatakan sembuh dan 895 kasus dinyatakan meninggal dunia.

Presiden RI Joko Widodo, juga telah mengumumkan kasus pertama positif COVID-19 di Indonesia pada Senin, 2 Maret 2020 yang ditularkan melalui transmisi dari manusia ke manusia. Berbagai upaya telah dilakukan oleh pemerintah RI, salah satunya dengan membentuk Gugus Tugas Percepatan Penanganan COVID-19 yang disahkan melalui Keputusan Presiden RI No.7 Tahun 2020, yang kemudian diperbaharui melalui Keputusan Presiden RI No.9 Tahun 2020. Adapun tujuan dari Gugus Tugas ini adalah meningkatkan ketahanan nasional dibidang kesehatan, meningkatkan sinergi antar kementerian/lembaga dan pemerintah daerah, antisipasi eskalasi peyebaran dan meningkatkan kesiapan, kemampuan dalam mencegah, emndetesi dan merespon COVID-19.

Hingga 18 Juni 2021, Pemerintah Republik Indonesia telah melaporkan 1.963.266 orang terkonfirmasi positif COVID-19 dan ada 54.043 kematian (CFR:2,8\%) terkait COVID-19 yang dilaporkan dan 1.779.127 pasien telah sembuh dari penyakit tersebut. Akibat hal ini, Presiden Joko Widodo mengumumkan penerapan Pemberlakuan Pembatasan Kegiatan Masyarakat (PPKM) Darurat yang berlaku mulai 3-20 Juli 2021. PPKM Darurat ini meliputi pembatasanpembatasan aktivitas masyarakat yang lebih ketat daripada yang selama ini sudah berlaku. Kebijakan yang diberlakukan selama dua pekan dan menyasar kabupaten/kota di Jawa dan Bali tersebut dilakukan sebagai salah satu cara untuk memutus rantai penyebaran virus corona, yang terus meningkat dalam beberapa waktu terakhir. Akibat kebijakan tersebut, pihak yang paling terdampak adalah para pelaku UMKM. Pelaku UMKM merupakan salah satu sektor usaha yang mengalami penurunan omset selama masa pandemi ini.

Salah satu kebijakan tersebut yang membahas tentang UMKM adalah bahwa dalam pelaksanaan kegiatan makan/minum ditempat umum (warung makan, rumah makan, kafe, pedagang kaki lima, lapak jajanan) baik yang berada pada lokasi tersendiri maupun yang berlokasi pada pusat perbelanjaan/mall hanya menerima delivery/take away dan tidak menerima makan ditempat (dine-in). Meskipun demikian, masih tetap saja antara pedagang dan konsumen tidak mematuhi kebijakan tersebut sehingga tidak jarang ditemukan penertiban oleh para TNI, Polri, dan Satpol PP di masyarakat yang masih nekat melanggar.

Dikutip dari berita Media Indonesia.com, Tanggal 09 Juli 2021, telah diberitakan bahwa Pengadilan Negeri (PN) Kelas I A Tasikmalaya, Jawa Barat, kembali menggelar sidang tatap muka bagi pelanggar pemberlakuan pembatasan kegiatan masyarakat (PPKM) darurat. Dalam sidang tindak piidana ringang (tipiring) tersebut, dilakukan di halaman dekat taman Kota Tasikmalaya, menghadirkan tiga penjual kopi kafe, pedagang bakso, dan pabrik ekspor pengolahan kayu PT Bina Kayone Lestari (BKL). Sidang pelanggaran PPKM darurat langsung dipimpin Ketua Majelis Hakim Pengadilan Negeri Kelas I A Tasikmalaya Moch Martin Helmi dan didampingi Panitera Ade Sajidin. Hakim memvonis tiga pemilik kafe dan penjual bakso masing-masing harus 
membayar denda Rp5 juta subsider kurungan 4 hari. Sedangkan pabrik ekspor pengolahan kayu bernama PT Bina Kayone Lestari (BKL) didenda Rp 6 juta subsider kurungan 5 bulan penjara.

Beberapa kalangan menilai sanksi tersebut terlalu memberatkan. Menteri Dalam Negeri (Mendagri) Tito Karnavian mengatakan bahwa hal tersebut sangat tergantung dari pemerintah daerah yang menetapkan bentuk sanksinya. Tito menjelaskan bahwa sebanarnya pemerintah daerah dapat mengeluarkan peraturan terkait PPKM darurat, akan tetapi dalam Perda tersebut sanksinya tidak boleh pidana sehingga hanya berlaku sanksi sosial misalnya, kerja sosial, kemudian juga sanksi administrasi misalnya penutupan tempat hiburan, tempat usaha dan lainlain.

Mengacu dengan apa yang disampaikan oleh Menteri Dalam Negeri (Mendagri) Tito Karnavian, seharusnya pada kasus pelaku UMKM di Tasikmalaya di atas, tidak perlu diberikan sanksi pidana berupa denda karena dinilai sangat memberatkan. Sehingga dalam hal ini, terjadi polemik antara peraturan dengan implementasi dilapangan. Hal ini diperkuat oleh Instruksi Menteri Dalam Negeri Nomor 15 Tahun 2021 tentang Pemberlakuan Pembatasan Kegiatan Masyarakat Darurat Corona Virus Disease 2019 di Wilayah Jawa dan Bali, di mana dalam intruksi ini tidak dijelaskan pemberlakuan sanksi berupa pidana bagi para pelanggarnya.

\subsection{Rumusan Masalah}

Dari latar belakang yang telah diuraikan di atas, dapat ditarik perumusan masalah dalam penelitian ini, yakni:

1. Bagaimana kebebasan berdagang di tengah PPKM darurat ditinjau dari sudut pandang sosiological jurisprudence.

2. Bagaimana kebebasan berdagang di tengah PPKM darurat ditinjau dari konsep keadilan.

\section{KAJIAN PUSTAKA}

\subsection{Kebebasan}

Kebebasan secara umum dimasukan dalam konsep dari filosofi politik dan mengenali kondisi di mana individu memiliki kemampuan untuk bertindak sesuai dengan keinginannya.

Kebebasan adalah esensi manusia, biasanya manusia yang bebas selalu menciptakan dirinya. Manusia yang bebas dapat mengatur, memilih dan dapat memberi makna pada realitas. Bagi manusia, eksistensi memiliki makna keterbukaan, berbeda dengan benda lain yang keberadaannya sekaligus esensinya.

Menurut Sartre manusia secara individual mempunyai kebebasan untuk mencipta dan memeberi makna kepada keberadaannya dengan merealisasikan kemungkinan-kemungkinan yang ada dengan merancang dirinya sendiri. Namun, ia tidak bisa sendirian, atau tidak bisa dilakukan perseorangan saja, tetapi harus berlangsung dalam konteks intersubyektivitas, yaitu bersama dengan yang lain.

Isaiah Berlin (1909-1997) adalah seorang filsuf politik yang banyak berbicara tentang teori kebebasan. Dalam hal ini, Berlin membedakan dua konsep kebebasan, yaitu: kebebasan positif (bebas untuk) dan kebebasan negatif (bebas dari). Bagi Berlin, kebebasan yang diperjuangkan dalam rumusan filsafat politikya adalah kebebasan negatif, bukan kebebasan positif. Menurut Berlin, konsep kebebasan positif (bebas untuk) adalah pandangan yang menyatakan bahwa manusia pada dasarnya bisa dan harus mengaktualisasikan potensi-potensi yang ada pada dirinya. Untuk itu, manusia bisa memilih tujuan yang ingin dicapai di dalam hidupnya, serta memperoleh sarana-sarana yang dapat mendukung bagi tercapainya tujuan hidup tersebut. Sementara itu, menurut Berlin, konsep kebebasan negatif (bebas dari) adalah pandangan yang mendukung agar manusia tidak boleh dipaksa untuk melakukan sesuatu apapun. Di sini, kata "negatif" memiliki konotasi logika (tidak/bukan), bukan konotasi moral (baik atau buruk). Artinya, "kebebasan negatif" adalah konsep kebebasan yang menekankan pentingnya untuk "tidak dipaksa."

Jika melihat konsep kebebasan ala barat, setidaknya ada dua kata yang cukup representatif untuk itu. Yakni freedom dan liberty, yang pengertiannya juga tidak jauh berbeda dengan apa yang telah kami abstraksikan di atas. Dimana konsep interpersonal atau social freedom 
menunjukkan pada hubungan interaktif antara person atau kelompok, dimana antara satu dengan yang lain memberikan kebebasan untuk melakukan sesuatu dalam berbagai bentuk cara.

\subsection{Konsep Sosiological Jurisprudence}

Roscoe Pound adalah salah satu ahli hukum yang beraliran sociological jurisprudence yang lebih mengarahkan perhatiannya pada "kenyataan hukum" daripada kedudukan dan fungsi hukum dalam masyarakat. Kenyataan hukum pada dasarnya adalah kemauan publik, jadi tidak sekedar hukum dalam pengertian law in books. Sociological Jurisprudence menunjukkan kompromi yang cermat antara hukum tertulis sebagai kebutuhan masyarakat hukum demi terciptanya kepastian hukum (positivism law) dan living law sebagai wujud penghargaan terhadap pentingnya peranan masyarakat dalam pembentukan hukum dan orientasi hukum.

Peran strategis hakim dalam perspektif sociological jurisprudence adalah menerapkan hukum tidak melulu dipahami sebagai upaya social control yang bersifat formal dalam menyelesaikan konflik, tetapi sekaligus mendesain penerapan hukum itu sebagai upaya social engineering. Tugas yudisial hakim tidak lagi dipahami sekedar sebagai penerap undang-undang terhadap peristiwa konkrit (berupa berbagai kasus dan konflik) atau sebagai sekedar corong undang-undang (boncha de la loi) tetapi juga sebagai penggerak social engineering. Para penyelenggara hukum harus memperhatikan aspek fungsional dari hukum yakni untuk mencapai perubahan, dengan melakukan perubahan hukum selalu dengan menggunakan segala macam teknik penafsiran (teori hukum fungsional).

Kepentingan negara adalah harus yang paling tinggi/atas dikarenakan negara mempunyai kepentingan nasional. Kepentingan nasional tersebut harus melindungi kepentingan negara kemauan negara adalah kemauan publik. Karena hukum itu bukan seperti yang dikatakan oleh teori-teori positivis menghukum bahwa hukum memiliki sifat tertutup. Hukum sangat dipengaruhi oleh ideologi, politik, ekonomi, sosial, budaya. Tidak hanya sekedar kemauan pemerintan. Suatu logika yang terbuka, perkembangan kebutuhan masyarakat sangat mempengaruhi pertumbuhan hukum di dalam masyarakat. Politik sangat mempengaruhi pertumbuhan hukum di dalam masyarakat.

\subsection{Keadilan}

Konsep keadian dalam filsafat hukum:

a. Keadilan menurut Plato

Plato adalah seorang pemikir idealis abstrak yang mengakui kekuatankekuatan diluar kemampuan manusia sehingga pemikiran irasional masuk dalam filsafatnya. Demikian pula halnya dengan masalah keadilan, Plato berpendapat bahwa keadilan adalah diluar kemampuan manusia biasa. Sumber ketidakadilan adalah adanya perubahan dalam masyarakat. Masyarakat memiliki elemen-elemen principal yang harus dipertahankan. Dari elemen-elemen prinsipal ini, elemen-elemen lainnya dapat diturunkan, misalnya berikut ini:

1) Kelas penguasa punya monopoli terhadap semua hal seperti keuntungan dan latihan militer, dan hak memiliki senjata dan menerima semua bentuk pendidikan, tetapi kelas penguasa ini tidak diperkenankan berpartisipasi dalam aktivitas perekonomian, terutama dalam usaha mencari penghasilan,

2) Harus ada sensor terhadap semua aktivitas intelektual kelas penguasa, dan propaganda terus-menerus yang bertujuan untuk menyeragamkan pikiranpikiran mereka. Semua inovasi dalam pendidikan, peraturan, dan agama harus dicegah atau ditekan.

3) Negara harus bersifat mandiri (self-sufficient). Negara harus bertujuan pada autarki ekonomi, jika tidak demikian, para penguasa akan bergantung pada para pedagang, atau justru para penguasa itu sendiri menjadi pedagang. Alternatif pertama melemahkan kekuasaan mereka, sedangkan alternative kedua akan melemahkan persatuan kelas penguasa dan stabilitas negaranya.

b. Keadilan Menurut Aristoteles 
Doktrin-doktrin Aristoteles tidak hanya meletakkan dasar-dasar bagi teori hukum, tetapi juga kepada filsafat barat pada umumnya. Kontribusi Aristoteles bagi filsafat hukum adalah formulasinya terhadap masalah keadilan, yang membedakan antara: keadilan "distributive" dengan keadilan "korektif" atau "remedial" yang merupakan dasar bagi semua pembahasan teoritis terhadap pokok persoalan. Keadilan distributive mengacu kepada pembagian barang dan jasa kepada setiap orang sesuai dengan kedudukannya dalam masyarakat, dan perlakuan yang sama terhadap kesederajatan dihadapan hukum (equality before the law).

Aristoteles menerangkan keadilan dengan ungkapan "justice consists in treating equals equally and unequalls unequally, in proportion to their inequality." Untuk hal-hal yang sama diperlakukan secara sama, dan yang tidak sama juga diperlakukan tidak sama, secara proporsional.

Aristoteles dalam mengartikan keadilan sangat dipengaruhi oleh unsure kepemilikan benda tertentu. Keadilan ideal dalam pandangan Aristoteles adalah ketika semua unsur masyarakat mendapat bagian yang sama dari semua benda yang ada di alam. Manusia oleh Aristoteles dipandang sejajar dan mempunyai hak yang sama atas kepemilikan suatu barang (materi).

c. Keadilan Menurut John Rawls

John Rawls menyatakan bahwa keadilan pada dasarnya merupakan prinsip dari kebijakan rasional yang diaplikasikan untuk konsepsi jumlah dari kesejahteraan seluruh kelompok dalam masyarakat. Untuk mencapai keadilan tersebut, maka rasional jika seseorang memaksakan pemenuhan keinginannya sesuai dengan prinsip kegunaan, karena dilakukan untuk memperbesar keuntungan bersih dari kepuasan yang diperoleh oleh anggota masyarakatnya.

Ketidaksamaan harus diberikan aturan yang sedemikian rupa sehingga paling menguntungkan golongan masyarakat paling lemah. hal ini terjadi kalau dua syarat dipenuhi. Pertama situasi ketidaksamaan menjamin maximum minorium bagi orang yang paling lemah. Artinya situasi masyarakat harus sedemikian rupa, sehingga dihasilkan untung yang paling tinggi yang mungkin dihasilkan bagi orang-orang kecil. kedua, ketidaksamaan diikat pada jabatanjabatan yang terbuka bagi semua orang. maksudnya setiap orang memiliki diberikan peluang yang sama besar dalam hidup.

Kesamaan dapat meletakkan prinsip-prinsip keadilan, karena pada dasarnya hukum harus menjadi penuntun agar orang dapat mengambil posisi yang adil dengan tetap memperhatikan kepentingan individunya, dan bertindak proposional sesuai dengan haknya serta tidak melanggar hukum yang berlaku. Dengan demikian keadilan sangat berkaitan dengan hak dan kewajiban para pihak dalam melaksanakan kesepakatan perjanjian sebagai bentuk tanggung jawabnya.

Dua prinsip keadilan Rawls di bawah ini merupakan solusi bagi problem utama keadilan.

1) Prinsip kebebasan yang sama sebesar-besarnya (principle of greatest equal liberty). Prinsip ini mencakup:

a) Kebebasan untuk berperan serta dalam kehidupan politik (hak bersuara, hak mencalonkan diri dalam pemilihan),

b) Kebebsan berbicara (termasuk kebebasan pers),

c) Kebebasan berkeyakinan (termasuk keyakinan beragama),

d) Kebebasan menjadi diri sendiri (person), dan

e) Hak untuk mempertahankan milik pribadi.

2) Prinsip keduanya ini terdiri dari dua bagian, yaitu prinsip perbedaan (the difference principle) dan prinsip persamaan yang adil atas kesempatan (the prinsiple of fair equality of opprtunity). Inti prinsip pertama adalah bahwa perbedaan sosial dan ekonomis harus diatur agar memberikan manfaat yang paling besar bagi mereka yang paling kurang beruntung. Istilah perbedaan sosio-ekonomis dalam prinsip perbedaan 
menuju pada ketidak samaan dalam prospek seorang untuk mendapatkan unsur pokok kesejahteraan, pendapatan dan otoritas. Sedang istilah yang paling kurang beruntung (paling kurang diuntungkan) menunjuk pada mereka yang paling kurang mempunyai peluang untuk mencapai prospek kesejahteraan, pendapatan dan otoritas.

\section{METODE PENELITIAN}

Metode pendekatan yang digunakan dalam penelitian ini adalah pendekatan yuridis normatif, dengan pengumpulan data sekunder. Peneliti memilih pendekataan normatif karena suasana yang masih dalam pandemi Covid-19 sehingga tidak memungkinkan jika penelitian ini dilakukan secara empiris. Tipe desain penelitian yang digunakan adalah Descriptive Design. Pengambilan data dalam penelitian ini adalah dengan studi pustaka. Analisis data dalam penelitian ini menggunakan tehnik analisis kualitatif yaitu untuk menjawab permasalahan penelitian, yaitu; bagaimana kebebasan berdagang di tengah PPKM darurat ditinjau dari sudut pandang sosiological jurisprudence dan konsep keadilan.

\section{HASIL DAN PEMBAHASAN}

\subsection{Kebebasan Berdagang di Tengah PPKM Darurat Ditinjau dari Sudut Pandang Sosiological Jurisprudence}

Sosiological jurisprudence dalam istilah lain disebut juga Functional anthropological (metode fungsional). Penyebutan ini dilakukan untuk menghindari kerancuan antara sosiological jurisprudence dan sosiologi hukum (the Sosiology of Law). Walaupun keduanya sama-sama membahas kajian tentang hukum, akan tetapi memiliki perbedaan. Sosiological jurisprudence merupakan cabang dari filsafat hukum sedangkan sosiology of Law adalah cabang dari sosiologi.

Roscoe Pound adalah salah satu ahli hukum yang beraliran sociological jurisprudence yang lebih mengarahkan perhatiannya pada "kenyataan hukum" daripada kedudukan dan fungsi hukum dalam masyarakat. Kenyataan hukum pada dasarnya adalah kemauan publik, jadi tidak sekedar hukum dalam pengertian law in books. Sociological Jurisprudence menunjukkan kompromi yang cermat antara hukum tertulis sebagai kebutuhan masyarakat hukum demi terciptanya kepastian hukum (positivism law) dan living law sebagai wujud penghargaan terhadap pentingnya peranan masyarakat dalam pembentukan hukum dan orientasi hukum.

Dalam menentukan arah kebijakan selama pandemi Covid-19 prioritas pemerintah harus mengacu kepada bidang kesehatan bukan kepada bidang lain semisal ekonomi. Hal ini penting dalam menjamin kesehatan warga negara karena ekonomi masih bisa di bangkitkan lagi ketika masa pandemi Covid-19 selesai, akan tetapi warga negara yang menjadi korban jiwa sudah tidak bisa dikembalikan lagi pastinya. Karena sebenarnya dalam slogan hukum juga sudah jelas ditegaskan bahwa keselamatan warga adalah hukum tertinggi atau Salus Populi Suprema Lex Esto. Jika meninjau pada kasus tukang bakso yang diberikan sanksi pidana denda di tengah PPKM darurat dan dihubungkan dengan konsep sociological jurisprudence, maka peran strategis hakim dalam perspektif sociological jurisprudence adalah menerapkan hukum tidak melulu dipahami sebagai upaya social control yang bersifat formal dalam menyelesaikan konflik, tetapi sekaligus mendesain penerapan hukum itu sebagai upaya social engineering. Tugas hakim tidak lagi dipahami sekedar sebagai penerap undang-undang terhadap peristiwa konkrit (berupa berbagai kasus dan konflik) atau sebagai sekedar corong undang-undang (boncha de la loi) tetapi juga sebagai penggerak social engineering. Seorang hakim harusnya memperhatikan aspek penerapan dari hukum yaitu hukum yang baik hendaknya sesuai dengan hukum yang hidup di dalam masyarakat. Sebab jika ternyata tidak, akibatnya ketentuan tersebut akan tidak dapat dilaksanakan dan akan mendapat tantangan-tantangan sehingga law as a tool of sosial engineering yang berarti hukum sebagai alat pembaharuan dalam masyarakat, diharapkan dapat berperan merubah nilai-nilai sosial dalam masyarakat tersebut. 
Jika mengacu pada konsep sociological jurisprudence, dapat diartikan bahwa Pemerintah Daerah yang mengeluarkan sanksi pidana berupa denda dalam peraturan PPKM darurat telah gagal dalam mewujudkan cita hukum, karena peran pembuat hukum harusnya menciptakan keseimbangan hak dalam masyarakat, bahkan pengadilan dengan pertimbangan hukumnya juga harus memberikan keadilan bagi anggota masyarakat yang kehilangan haknya. Sanksi denda seharusnya dijadikan sebagai opsi terakhir dalam penentuan sanksi pelanggaran PPKM darurat karena jika mengacu pada konsep di atas maka sanksi sosial lah yang harusnya dikedepankan, mengingat bahwa hukum tidak sekedar menurut undang-undang, tetapi lebih mempertimbangkan keadilan pada realitas publik. Artinya bahwa sebenarnya hukum juga masih mempunyai sisi yang lain, yakni tampak pada kenyataan sosial sebagaimana hukum itu dijalankan sehari-harinya oleh masyarakat.

Dari uraian tersebut di atas dapat ditarik kesimpulan bahwa secara konsep sociological jurisprudence, berdagang di tengah PPKM darurat merupakan hak masyarakat yang menjadi realitas publik yang harusnya tetap dipantau dan dikontrol tanpa penjatuhan sanksi denda meskipun asas Salus Populi Suprema Lex Esto menjadi landasan dalam implementasi sanksi tersebut. Akan tetapi, paling tidak cita hukum harus tetap dipertimbangkan demi merubah nilai-nilai sosial dalam masyarakat tersebut.

\subsection{Kebebasan Berdagang di Tengah PPKM Darurat Ditinjau dari Konsep Keadilan}

Kata "keadilan" dalam bahasa Inggris adalah "justice" yang berasal dari bahasa latin "iustitia". Kata "justice" memiliki tiga macam makna yang berbeda yaitu;

a. Secara atributif berarti suatu kualitas yang adil atau fair (sinonimnya justness),

b. Sebagai tindakan berarti tindakan menjalankan hukum atau tindakan yang menentukan hak dan ganjaran atau hukuman (sinonimnya judicature), dan

c. Orang, yaitu pejabat publik yang berhak menentukan persyaratan sebelum suatu perkara di bawa ke pengadilan (sinonimnya judge, jurist, magistrate).

Dalam konsep Plato tentang keadilan dikenal adanya keadilan individual dan keadilan dalam negara. Untuk menemukan pengertian yang benar mengenai keadilan individual, terlebih dahulu harus ditemukan sifat-sifat dasar dari keadilan itu dalam negara, untuk itu Plato mengatakan: "let us enquire first what it is the cities, then we will examine it in the single man, looking for the likeness of the larger in the shape of the smaller". Walaupun Plato mengatakan demikian, bukan berarti bahwa keadilan individual identik dengan keadilan dalam negara. Hanya saja Plato melihat bahwa keadilan timbul karena penyesuaian yang memberi tempat yang selaras kepada bagian-bagian yang membentuk suatu masyarakat. Keadilan terwujud dalam suatu masyarakat bilamana setiap anggota melakukan secara baik menurut kemampuannya fungsi yang sesuai atau yang selaras baginya.

Konsepsi keadilan Plato yang demikian ini dirumuskan dalam ungkapan "giving each man his due" yaitu memberikan kepada setiap orang apa yang menjadi haknya. Untuk itu hukum perlu ditegakkan dan Undang-undang perlu dibuat. Dalam kaitannya dengan hukum, obyek materianya adalah masalah nilai keadilan sebagai inti dari asas perlindungan hukum, sedangkan obyek formanya adalah sudut pandang normatif yuridis dengan maksud menemukan prinsip dasar yang dapat diterapkan untuk menyelesaikan masalah yang timbul di bidang penggunaan nilai keadilan dimaksud. Tentang nilai keadilan yang dimaksud terutama yang berkenaan dengan obyeknya yaitu hak yang harus diberikan kepada warga masyarakat. Biasanya hak ini dinilai dan diperlakukan dari berbagai aspek pertimbangan politik dan budaya, namun intinya tetap tidak berubah yaitu suum cuique tribuere.

Plato memandang suatu masalah yang memerlukan pengaturan dengan undangundang harus mencerminkan rasa keadilan, sebab bagi Plato hukum dan undang-undang bukanlah semata-mata untuk memelihara ketertiban dan menjaga stabilitas negara, melainkan yang paling pokok dari undang-undang adalah untuk membimbing masyarakat mencapai keutamaan, sehingga layak menjadi warga negara dari negara yang ideal. Hukum dan undangundang bersangkut paut erat dengan kehidupan moral dari setiap warga masyarakat. Untuk mewujudkan keadilan masyarakat harus dikembalikan pada struktur aslinya, domba menjadi 
domba, penggembala menjadi penggembala. Tugas ini adalah tugas negara untuk menghentikan perubahan. Dengan demikian keadilan bukan mengenai hubungan antara individu melainkan hubungan individu dan negara. Bagaimana individu melayani negara.

Berbeda dengan Plato, Aristoteles menekankan teorinya pada perimbangan atau proporsi. Menurutnya di dalam negara segala sesuatunya harus diarahkan pada cita-cita yang mulia yaitu kebaikan dan kebaikan itu harus terlihat lewat keadilan dan kebenaran. Penekanan perimbangan atau proporsi pada teori keadilan Aristoteles, dapat dilihat dari apa yang dilakukannya bahwa kesamaan hak itu haruslah sama diantara orang-orang yang sama. Maksudnya pada satu sisi memang benar bila dikatakan bahwa keadilan berarti juga kesamaan hak, namun pada sisi lain harus dipahami pula bahwa keadilan juga berarti ketidaksamaan hak. Teori keadilan Aristoteles berdasar pada prinsip persamaan. Dalam versi modern teori itu dirumuskan dengan ungkapan bahwa keadilan terlaksana bila hal-hal yang sama diperlukan secara sama dan hal-hal yang tidak sama diperlakukan secara tidak sama.

Aristoteles membedakan keadilan menjadi keadilan distributif dan keadilan komutatif. Keadilan distributif adalah keadilan yang menuntut bahwa setiap orang mendapat apa yang menjadi haknya, jadi sifatnya proporsional. Di sini yang dinilai adil adalah apabila setiap orang mendapatkan apa yang menjadi haknya secara proporsional. Keadilan distributif berkenaan dengan penentuan hak dan pembagian hak yang adil dalam hubungan antara masyarakat dengan negara, dalam arti apa yang seharusnya diberikan oleh negara kepada warganya. Hak yang diberikan dapat berupa benda yang tak bisa dibagi (undivided goods) yakni kemanfaatan bersama misalnya perlindungan, fasilitas publik baik yang bersifat administratif maupun fisik dan berbagai hak lain, di mana warga negara atau warga masyarakat dapat menikmati tanpa harus menggangu hak orang lain dalam proses penikmatan tersebut. Selain itu juga benda yang habis dibagi (divided goods) yaitu hak-hak atau bendabenda yang dapat ditentukan dan dapat diberikan demi pemenuhan kebutuhan individu pada warga dan keluarganya, sepanjang negara mampu untuk memberikan apa yang dibutuhkan para warganya secara adil, atau dengan kata lain dimana terdapat keadilan distributif, maka keadaan tersebut akan mendekati dengan apa yang disebut keadaan dimana tercapainya keadilan sosial bagi masyarakat. Sebaliknya keadilan komutatif menyangkut mengenai masalah penentuan hak yang adil di antara beberapa manusia pribadi yang setara, baik diantara manusia pribadi fisik maupun antara pribadi non fisik. Dalam hubungan ini suatu perserikatan atau perkumpulan lain sepanjang tidak dalam arti hubungan antara lembaga tersebut dengan para anggotanya, akan tetapi hubungan antara perserikatan dengan perserikatan atau hubungan antara perserikatan dengan manusia fisik lainnya, maka penentuan hak yang adil dalam hubungan ini masuk dalam pengertian keadilan komutatif. Obyek dari hak pihak lain dalam keadilan komutatif adalah apa yang menjadi hak milik seseorang dari awalnya dan harus kembali kepadanya dalam proses keadilan komutatif. Obyek hak milik ini bermacam-macam mulai dari kepentingan fisik dan moral, hubungan dan kualitas dari berbagai hal, baik yang bersifat kekeluargaan maupun yang bersifat ekonomis, hasil kerja fisik dan intelektual, sampai kepada hal-hal yang semula belum dipunyai atau dimiliki akan tetapi kemudian diperoleh melalui cara-cara yang sah. Ini semua memberikan kewajiban kepada pihak lain untuk menghormatinya dan pemberian sanksi berupa ganti rugi bila hak tersebut dikurangi, dirusak atau dibuat tidak berfungsi sebagaimana mestinya.

Jika kasus pada pemberlakuan sanksi pidana berupa denda di tengah PPKM darurat bagi para pelaku UMKM seperti penjual bubur dan penjual bakso sebagaimana yang telah dikemukakan di awal dan di hubungkan dengan Pasal 28A UUD 1945, menyebutkan bahwa, setiap orang berhak untuk hidup serta berhak mempertahankan hidup dan kehidupannya. Maka dapat diartikan bahwa Pemerintah telah memutus mata pencaharian masyarakat. Dilanjutkan dengan Pasal 28D ayat (2) yang menyebutkan bahwa setiap orang berhak untuk bekerja serta mendapat imbalan dan perlakuan yang adil dan layak dalam hubungan kerja. Maka dapat diartikan bahwa Pemerintah secara tidak langsung telah menggangu hak masyarakat dalam proses penikmatan tersebut. Padahal pada Pasal 12 ayat (1) UU No. 7/2014 
tentang Perdagangan disebutkan bahwa Pemerintah, Pemerintah Daerah, dan/atau Pelaku Usaha secara sendiri-sendiri atau bersama-sama mengembangkan sarana perdagangan. Kemudian Pasal 95 huruf h juga menyebutkan bahwa Pemerintah Daerah salah satunya bertugas menciptakan iklim usaha yang kondusif.

Hal tersebut di atas menunjukkan bahwa Pemerintah telah melupakan konsep keadilan distributif yang menuntut bahwa setiap orang mendapat apa yang menjadi haknya, sedangkan berdagang adalah hak setiap orang untuk mempertahankan hidup dan kehidupanya. Tidak hanya itu, Pemerintah juga telah melupakan konsep keadilan komutatif yang telah menyangkut mengenai masalah penentuan hak yang adil di antara beberapa pedagang di mana hasil kerja fisik yang dilakukan harusnya menjadi kewajiban Pemerintah untuk menghormatinya.

Dari uraian tersebut di atas dapat ditarik kesimpulan bahwa secara konsep keadilan, berdagang di tengah PPKM darurat merupakan hak setiap orang untuk mempertahankan hidup dan kehidupanya yang telah dirumuskan oleh hukum dalam bentuk hak dan kewajiban. Hal ini menegaskan bahwa Pemerintah tetap harus memperhatikan suatu keadilan dengan mempertimbangkan faktor ekonomi dan sosial, yang tentunya harus relevan dengan ketertiban umum dimana suatu skala keadilan diakui.

\section{KESIMPULAN}

Dari seluruh hasil pembahasan yang telah dipaparkan, peneliti menyimpulkan:

1. Bahwa sociological jurisprudence lebih mengarahkan perhatiannya pada "kenyataan hukum" daripada kedudukan dan fungsi hukum dalam masyarakat. Kenyataan hukum secara konsep sociological jurisprudence, berdagang di tengah PPKM darurat merupakan hak masyarakat yang menjadi realitas publik yang harusnya tetap dipantau dan dikontrol tanpa penjatuhan sanksi denda meskipun asas Salus Populi Suprema Lex Esto menjadi landasan dalam implementasi sanksi tersebut. Akan tetapi, paling tidak cita hukum harus tetap dipertimbangkan demi merubah nilai-nilai sosial dalam masyarakat tersebut.

2. Bahwa konsepsi keadilan merupakan "giving each man his due" yaitu memberikan kepada setiap orang apa yang menjadi haknya. Secara konsep keadilan, berdagang di tengah PPKM darurat merupakan hak setiap orang untuk mempertahankan hidup dan kehidupanya yang telah dirumuskan oleh hukum dalam bentuk hak dan kewajiban. Hal ini menegaskan bahwa Pemerintah tetap harus memperhatikan suatu keadilan dengan mempertimbangkan faktor ekonomi dan sosial, yang tentunya harus relevan dengan ketertiban umum dimana suatu skala keadilan diakui.

\section{DAFTAR PUSTAKA}

\section{BUKU}

Aris Prio Agus Santoso, dkk, 2020, Pengantar Filsafat Hukum, Yogyakarta: Pustaka Baru Press.

---------, 2020, Hukum Administrasi Negara, Yogyakarta: Pustaka Baru Press.

---------, 2020, Pengantar Ilmu Hukum, Yogyakarta: Pustaka Baru Press.

---------, 2020, Hukum Ketenagakerjaan dan Penyelesaian Perselisihan Hubungan Industrial, Yogyakarta: Pustaka Baru Press.

---------, 2021, Hukum Dan Politik: Pengaruh dan Peranan Politik Hukum Bagi Negara, Yogyakarta: Pustaka Baru Press.

Carl Joachim Friedrich, 2004, Filsafat Hukum Perspektif Historis, Bandung: Nuansa dan Nusamedia.

Gugus Tugas Percepatan Penanganan COVID-19, 2020, Protokol Percepatan Penanganan Pandemi Covid-19 (Corona Virus Disease 2019), Jakarta: Gugus Tugas Percepatan Penanganan COVID-19.

Hyronimus Rhiti, 2015, Filsafat Hukum Edisi Lengkap (Dari Klasik ke Postmodernisme), Yogyakarta: Universitas Atma Jaya. 
M. Agus Santoso, 2014, Hukum, Moral dan Keadilan: Sebuah Kajian Filsafat Hukum, Jakarta: Kencana.

Sukendar, dkk, 2020, Teori Hukum: Suatu Penagntar, Yogyakarta: Pustaka Baru Press.

\section{JURNAL}

Aris Prio Agus Santoso, dan Tatiana Siska Wardani, "Juridical Analysis of Nurse Authority in Granting of Red Label Drugs in The Mandiri Nursing Practice”, SOEPRA: Jurnal Hukum Kesehatan, Vol. 6, No. 1, 2019.

Aris Prio Agus Santoso, dan Erna Chotidjah Suhatmi, "Employment Termination In The Middle Of Covid-19 Pandemic: Labor Law Point Of View", UNIFIKASI: Jurna Ilmu Hukum, Vol. 8, No.1, 2021.

Aris Prio Agus Santoso, dkk, "Perlindungan Hukum Tenaga Kesehatan dalam Gugus Tugas Percepatan Penanganan Covid-19 Ditinjau dari Sudut Pandang Hukum Administrasi Negara", Jurnal Ilmu Sosial dan Pendidikan (JISIP), Vol. 5, No. 2, 2021.

Aris Prio Agus Santoso, dkk, "Analisis Yuridis Pemberian Upah di Bawah UMk Bagi Tenaga Kesehatan di Rumah Sakit", Jurnal Ilmu Sosial dan Pendidikan (JISIP), Vol. 5, No. 3, 2021.

Aris Prio Agus Santoso, dkk, "Legal Protection of Health Workers in the Task Force for the Acceleration of Handling Covid-19 from a State Administrative Law Point of View", Jurnal Ilmu Sosial dan Pendidikan (JISIP), Vol. 5, No. 2, 2021.

Bahder Johan Nasution, "Kajian Filosofis Tentang Konsep Keadilan dari Pemikiran Klasik Sampai Pemikiran Modern", Yustisia, Vol. 3, No. 2, 2014.

Dahlia Halia Ma'u, dan Muliadi Nur, "Paradigma Hukum Sosiologis (Upaya Menemukan Makna Hukum dari Realitas Publik)", Jurnal Ilmiah Al-Syir'ah, Vol. 7, No. 2, 2016.

Firdaus M. Yunus, "Kebebasan dalam Filsafat Eksistensialisme Jean Paul Sartre”, Jurnal AlUlum Vol. 11, No. 2, 2011.

Idah Wahidah, dkk, "Pandemik Covid-19: Analisis Perencanaan Pemerintah dan Masyarakat dalam Berbagai Upaya Pencegahan”, Jurnal Manajemen dan Organisasi (JMO), Vol. 11 No. 3, 2020.

Marsudi Dedi Putra, “Kontribusi Aliran Sociological Jurisprudence Terhadap Pembangunan Sistem Hukum Indonesia", LIKHITAPRAJNA (Jurnal Ilmiah.Fakultas Keguruan dan Ilmu Pendidikan), Vol. 16, No. 2, 2014.

Muhammad Helmi, "Konsep Keadilan dalam Filsafat Hukum dan Filsafat Hukum Islam", MAZHABIB: Jurnal Pemikiran Hukum Islam, Vol. 14, No. 2, 2015.

Taufik Effendy, “Rahasia Dagang Sebagai Bagian dari Hak Kekayaan Intelektual”, Al'Adl, Vol. 6, No. 12,2014

Yulia Emma Sigalingging, dan Aris Prio Agus Santoso, “Analisis Yuridis Pengaturan Sanksi Bagi Penolak Vaksinasi Covid-19”, Jurnal Ilmu Sosial dan Pendidikan (JISIP), Vol. 5, No. 3, 2021.

\section{PERATURAN}

RI, UUD 1945.

RI, Undang-Undang Nomor 7 Tahun 2014 tentang Perdagangan.

RI, Instruksi Menteri Dalam Negeri Nomor 15 Tahun 2021 tentang Pemberlakuan Pembatasan Kegiatan Masyarakat Darurat Corona Virus Disease 2019 di Wilayah Jawa dan Bali.

\section{INTERNET}

Media Indonesia, 2019, "Setelah Penjual Bubur, Kini Tukang Bakso Diganjar Denda Rp5 Juta karena Melanggar PPKM Darurat", diakses pada: https://www.medcom.id/nasional/daerah/8Kyj7azN-setelah-penjual-bubur-kinitukang-bakso-diganjar-denda-rp5-juta-karena-melanggar-ppkm-darurat (Tanggal 17 Juli 2019 Pukul 20.00 WIB). 